BIOFARM

Jurnal Ilmiah Pertanian

ISSN Print: 0216-5430; ISSN Online: 2301-6442

Vol. 14, No. 2, Oktober 2018

\title{
Pengaruh Macam Zat Pengatur Tumbuh Alami terhadap Pertumbuhan Setek Beberapa Klon Kopi Robusta (Coffea canephora)
}

\author{
Effect of Substance Types of Natural Growth Regulators on Growth of Some \\ Robusta Coffee Clones Cuttings (Coffea canephora)
}

Rofiul Azmi ${ }^{1 *}$ dan Ari Handriatni

Program Studi Agroteknologi, Fakultas Pertanian, Universitas Pekalongan

*Korespondensi Penulis: rofiul azmi@rocketmail.com

\begin{abstract}
ABSTRAK
Penelitian ini bertujuan untuk mengetahui pengaruh macam zat pengatur tumbuh alami dan klon kopi Robusta serta interaksinya terhadap pertumbuhan setek kopi Robusta. Penelitian dilakukan di Desa Mesoyi Kecamatan Talun Kabupaten Pekalongan. Penelitian ini disusun dalam Rancangan Acak Kelompok (RAK) yang terdiri atas 2 faktorial dengan ulangan 3 kali. Data dianalisis dengan uji $\mathrm{F}$ dan dilanjutkan dengan uji BNT taraf $5 \%$. Faktor pertama macam zat pengatur tumbuh meliputi (air kelapa muda, ekstrak kecambah kacang hijau, urin sapi), faktor kedua macam klon kopi Robusta (BP 409, BP 42, BP 288, SA 34). Variabel pengamatan meliputi kecepatan tumbuh tunas, persentase setek tumbuh, panjang tunas, jumlah daun, jumlah akar, panjang akar, bobot basah tanaman, bobot basah akar, bobot kering tanaman, bobot kering akar. Hasil penelitian menunjukkan macam zat pengatur tumbuh alami berbeda sangat nyata terhadap semua variabel kecuali berbeda nyata terhadap variabel kecepatan tumbuh tunas, bobot basah akar, dan bobot kering akar.Perlakuan macam zat pengatur tumbuh terbaik adalah air kelapa muda.Hasil penelitian menunjukkan macam klon kopi Robusta berbeda sangat nyata terhadap variabel persentase setek tumbuh, panjang tunas, jumlah daun, jumlah akar,bobot basah tanaman, bobot kering tanaman, berbeda nyata terhadap variabel panjang akar, bobot basah akar, bobot keing akar, dan tidak berbeda nyata terhadap variabel kecepatan tumbuh tunas.Klon kopi Robusta terbaik adalah BP 409.Terdapat interaksi antara macam zat pengatur tumbuh alami dan macam klon kopi Robusta. Interaksi terbaik dicapai pada kombinasi perlakuan air kelapa muda dan klon kopi Robusta BP 409.
\end{abstract}

Kata kunci: kopi robusta, ZPT alami, setek

\section{ABSTRACT}

This research aims to determine the effect of natural growth regulator and Robusta coffee clones and their interaction with the growth of Robusta coffee cuttings. The study was conducted in Mesoyi Village, Talun, Pekalongan. The design used randomized block design. consisting of 2 factorials with 3 replications. Data were analyzed by $F$ test and continued with BNT test of $5 \%$ level. The first factors is kind of growth regulators substance (young coconut water, green bean sprout extract, cow urine), second factor Robusta coffee clones (BP 409, BP 42, BP 288, SA 34). Observation variables include shoot growth rate, percentage of growing cuttings, shoot length, number of leaves, root number, root length, wet weight of plant, wet root weight, plant dry weight, dry root weight. The results showed that the natural growth regulator substances differed significantly among all variables except for the variables of shoot growth rate, root wet weight, and root dry weight. The best kind of growth regulator treatment is young coconut ar. The results showed that Robusta coffee clones differed significantly from percentage of growing cuttings, shoot length, leaf number, root quantity, wet weight of plant, dry weight of plant, significantly different to root length variables, root wet weight, root weights, and no Significantly different to the variables of shoot growing rate. The best Robusta coffee clone is BP 409. There is an interaction between various natural growth regulators and Robusta coffee clones. The best interaction was achieved in a combination of young coconut water treatment and Robusta BP 409 coffee clones.

Keywords: robusta coffee, natural ZPT, cuttings

\section{PENDAHULUAN}

Kopi (coffea sp) merupakan tanaman perkebunan yang sudah lama dibududayakan. Selain sebagai sumber penghasilan rakyat, kopi menjadi komoditas andalan ekspor dan sumber pendapatan devisa Negara. Meskipun demikian, komoditas kopi sering kali mengalami fluktuasi harga sebagai akibat ketidakseimbangan antara permintaan dan persediaan komoditas kopi di pasar dunia (Rahardjo, 2012).

Saat ini Indonesia menjadi produsen utama kopi ketiga setelah Brasil dan Vietnam. Luas tanaman kopi di Indonesia 1.292.965 ha 
(tahun 2011) dengan produksi 633.991 ton dan sekitar $96 \%$ diusahakan oleh rakyat. Kopi Indonesia tergolong dalam dua jenis kopi yaitu kopi Arabika dan kopi Robusta. Keunggulan kopi Arabika adalah kopi ini mempunyai cita rasa yang bersifat khas sehingga pasarnya pun khusus, sedangkan kopi robusta merupakan salah satu komoditas yang memiliki nilai strategis dalam rangka pemberdayaan ekonomi rakyat. Prospek komoditi kopi Indonesia sangat besar karena didukung adanya ketersediaan lahan pengembangan kopi serta Indonesia memiliki keunggulan geografis dan iklim yang menghasilkan kopi yang mempunyai cita rasa dan aroma yang digemari masyarakat dunia (Direktorat Jenderal Perkebunan, 2013).

Perbanyakan tanaman kopi dapat dilakukan dengan cara vegetaif dan generative. Perbanyakan generative menggunakan bagian generative tanaman kopi untuk perbanyakan, yaitu benih (biji). Sementara itu perbanyakan dengan cara vegetative, yaitu menggunakan bagian vegetative tanaman kopi, seperti daun, ranting, cabang, dan akar untuk perbanyakan tanaman. Cara perbanyakan vegetaif, diantaranya setek dan dan sambung terutama untuk kopi jenis Robusta. (Rahardjo, 2012).

Perbanyakan vegetatif salah satunya adalah dengan cara setek, diharapkan dapat terjamin sifat-sifat yang sama dengan indukannya. Agar pembangunan di bidang perkebunan yang telah direncanakan pemerintah dapat segera terwujud, maka perlu adanya upaya dalam cara pelaksanaannya, sehingga pada saat tanam selalu tersedia bibit dalam jumlah cukup, tepat waktu dan berkualitas tinggi. Indikasi keberhasilan penyetekan adalah timbulnya akar dan tunas. Usaha untuk mempercepat timbulnya akar dan tunas pada setek kopi dapat di tempuh dengan pemberian zat perangsang tumbuh (Kiptiyah, 2005).

ZPT adalah senyawa organik yang bukan hara (nutrien), yang dalam jumlah sedikit dapat mendukung, menghambat dan dapat merubah proses fisiologi tumbuhan. ZPT terdiri dari lima yaitu auksin yang mempunyai kemampuan dalam mendukung perpanjangan sel, giberelin dapat menstimulasi pembelahan sel, pemanjangan sel atau keduanya, sitokinin mendukung terjadinya pembelahan sel, ethilen berperan dalam proses pematangan buah, dan asam absisat. ZPT secara garis besarnya dapat dibagi atas dua golongan, yaitu alami dan sintetis seperti urine sapi, air kelapa, ekstrak kecambah kacang hijau, ekstrak bawang merah yang termasuk ZPT alami (Bhimas, 2010).

Dari banyaknya klon-klon kopi Robusta maka perlu dicari mana yang termasuk baik untuk ditanam, dan setelah diadakan pengujian kembali secara lokal, yang dianjurkan untuk ditanam secara besar-besaran adalah klon-klon BP 42, BP 288, BP 358, BP 409, BP 234 SA 237. Namun untuk keberhasilan setek dari beberapa klon kopi Robusta ini memiliki persentase yang berbeda. Menurut Rahardjo (2012) klon-klon kopi Robusta mempunyai persentase keberhasilan setek yang berbeda seperti BP 409 yang memiliki pesentase setek mencapai $75 \%$ kemudian ada BP 42 yang memiliki persentase mencapai $60 \%$ dan klon-klon lain yang mempunyai persentase yang berbeda pula. Penelitian ini dilakukan dengan tujuan untuk mengetahui macam ZPT alami yang tepat untuk pertumbuhan setek kopi, mengetahui klon kopi Robusta mana yang pertumbuhan seteknya terbaik dan mengetahui interaksi antara macam ZPT alami dan klon kopi Robusta terhadap peningkatan pertumbuhan setek kopi.

\section{BAHAN DAN METODE}

Percobaan telah dilaksanakan di Desa Mesoyi, Kecamatan Doro, Kabupaten Pekalongan pada ketinggian tempat \pm 450 meter di atas permukaan laut ( $\mathrm{m} \mathrm{dpl}$ ). Percobaan dilaksanakan selama 3 bulan, yaitu mulai bulan Agustus sampai dengan Oktober 2016. Rancangan yang akan digunakan dalam percobaan ini adalah Rancangan Acak Kelompo (RAK) dengan tiga kali ulangan yang terdiri atas dua faktor, Macam zat pengatur tumbuh yang terdiri atas M1: air kelapa muda, M2: ekstrak kecambah kacang hijau, M3: urin sapi, dan Macam klon kopi Robusta yang terdiri atas K1: BP 409, K2: BP 42, K3: BP 
288, K4: SA 34. Dengan demikian terdapat 12 kombinasi perlakuan, masing-masing kombinasi diulang tiga kali sehingga seluruhnya ada $(3 \times 4) \times 3=36$ satuan percobaan.

Variabel yang diamati meliputi: kecepatan tumbuh tunas, persentase setek tumbuh, panjang tunas, jumlah daun, jumlah akar, panjang akar, bobot basah tanaman, bobot basah akar, bobot kering tanaman, bobot kering akar. Data yang diperoleh dianalisis dengan Uji F. Jika antara faktor yang dicoba terdapat beda nyata maka dilanjutkan dengan Uji BNT 5\%. Faktor macam ZPT alami dan macam klon kopi Robusta dianalisis dengan menggunakan uji kontras orthogonal.

\section{HASIL DAN PEMBAHASAN}

Matrik hasil analisis data penelitian pengaruh macam ZPT alami dan macam klon kopi Robusta terhadap pertumbuhan setek beberapa klon kopi Robusta (Coffea canephora.) disajikan pada Tabel 1. Angka rata-rata dan analisis statistik data komponen pertumbuhan setek klon kopi Robusta pada Tabel 2, sedangkan angka rata- rata pengaruh interaksi antara macam ZPT alami dan macam klon kopi Robusta pada Tabel 3.

Tabel 1. Matrik Hasil Analisis Statistik Pengaruh Macam ZPT Alami dan Macam klon kopi Robusta terhadap pertumbuhan setek beberapa klon kopi Robusta (Coffea canephora.)

\begin{tabular}{clccc}
\hline & \multicolumn{2}{c}{ Variabel yang diamati } & \multicolumn{3}{c}{ Faktor yang dicoba } \\
\cline { 3 - 5 } No. & & Defoliasi & $\begin{array}{c}\text { Pemberian } \\
\text { pupuk phospat }\end{array}$ & Interaksi \\
\hline 1 & Kecepatan tumbuh tunas (hari) & $*$ & tn & tn \\
2 & Persentase setek tumbuh (\%) & $* *$ & $* *$ & tn \\
3 & Panjang tunas (cm) & $* *$ & $* *$ & $*$ \\
4 & Jumlah daun (helai) & $* *$ & $* *$ & tn \\
5 & Jumlah akar (buah) & $* *$ & $*$ & tn \\
6 & Panjang akar (cm) & $*$ & $*$ & $*$ \\
7 & Bobot basah tanaman (gram) & $* *$ & $*$ & tn \\
8 & Bobot basah akar (gram) & $*$ & $*$ & tn \\
9 & Bobot kering tanaman (gram) & & $* *$ \\
10 & Bobot kering tanaman (gram) & &
\end{tabular}

Keterangan:

${ }^{* *}$ : Berbeda sangat nyata, ${ }^{*}$ : Berbeda nyata, tn : Tidak berbeda nyata

\section{Pengaruh macam Zat Pengatur Tumbuh alami}

Hasil penelitian menunjukkan bahwa macam ZPT alami berbeda nyata terhadap kecepatan tumbuh tunas tanaman. Kecepatan tumbuh tunas tanaman tercepat dicapai pada perlakuan macam ZPT alami air kelapa muda $\left(M_{1}\right)$, diikuti Urin sapi $\left(M_{3}\right)$, sedangkan kecepatan tumbuh tunas terendah pada perlakuan ekstrak kecambah kacang hijau $\left(M_{2}\right)$. Hal ini karena pemberian auksin eksogen (dari luar) akan meningkatkan aktifitas auksin endogen yang sudah ada pada stek, sehingga mendorong pembelahan sel dan menyebabkan tunas muncul lebih awal, dari ketiga zat pengatur tumbuh diatas samasama mengandung hormon auksin dalam jumlah yang berbeda.
Pemberian auksin dari luar dengan konsentrasi yang tepat mampu memacu pertumbuhan organ vegetatif tanaman seperti tunas, dengan pemberian auksin eksogen dapat menambah serta memacu aktivitas auksin endogen yang sudah ada pada stek tersebut sehingga dapat memacu tumbuhnya tunas pada setek lebih awal dari pada setek yang tidak diberi zat pengatur tumbuh dari luar. Hal ini sejalan dengan pernyataan (Aguzen, 2009) bahwa pemberian air kelapa mampu meningkatkan pertumbuhan tunas, tajuk dan daun pada stek yang disebabkan oleh keberadan hormons auksin, sitokinin dan giberelin yang terkandung dalam air kelapa, setelah diserap dan ditranslokasikan ke tunas stek dapat merangsang dan memacu pertumbuhan tunas stek. 
Tabel 2. Angka Rata-rata dan Analisis Statistik Data Komponen Pertumbuhan Setek Klon Kopi Robusta

\begin{tabular}{llllll}
\hline Perlakuan & $\begin{array}{c}\text { Kecepatan } \\
\text { tumbuh tunas } \\
\text { (hari) }\end{array}$ & $\begin{array}{c}\text { Persentase } \\
\text { setek tumbuh } \\
(\%)\end{array}$ & $\begin{array}{c}\text { Panjang } \\
\text { tunas } \\
(\mathrm{cm})\end{array}$ & $\begin{array}{c}\text { Jumlah } \\
\text { daun } \\
\text { (helai) }\end{array}$ & $\begin{array}{c}\text { Jumlah } \\
\text { akar } \\
\text { (buah) }\end{array}$ \\
\hline Macam ZPT Alami & $21,27 \mathrm{a}$ & $73,33 \mathrm{~b}$ & $3,91 \mathrm{~b}$ & $4,62 \mathrm{c}$ & $2,43 \mathrm{~b}$ \\
M1 : Air Kelapa & $22,48 \mathrm{~b}$ & $60,00 \mathrm{a}$ & $2,72 \mathrm{a}$ & $3,50 \mathrm{~b}$ & $2,09 \mathrm{a}$ \\
M2 : Ekstrak Kecambah & $22,47 \mathrm{~b}$ & $58,33 \mathrm{a}$ & $2,65 \mathrm{a}$ & $3,43 \mathrm{a}$ & $1,92 \mathrm{a}$ \\
M3 : Urin Sapi & $14,93^{\star *}$ & $6,42^{\star *}$ & $20,20^{\star *}$ & $28,05^{* *}$ & $7,36^{\star *}$ \\
\hline F Hitung & 3,44 & 3,44 & 3,44 & 3,44 & 3,44 \\
F Tabel 5\% & 5,72 & 5,72 & 5,72 & 5,72 & 5,72 \\
F Tabel 1\% & 1,84 & 19,03 & 0,92 & 0,74 & 0,57 \\
\hline BNT 5\% & 0,05 & 0,18 & 0,18 & 0,11 & 0,16 \\
\hline KK & & & & & \\
\hline Macam Klon Kopi Robusta & 21,38 & $73,33 \mathrm{c}$ & $4,24 \mathrm{~d}$ & $4,42 \mathrm{c}$ & $2,69 \mathrm{~d}$ \\
K1 : BP 409 & 21,87 & $73,33 \mathrm{c}$ & $3,29 \mathrm{c}$ & $3,87 \mathrm{~b}$ & $2,29 \mathrm{c}$ \\
K2 : BP 42 & 22,64 & $46,67 \mathrm{a}$ & $2,17 \mathrm{a}$ & $3,36 \mathrm{a}$ & $1,60 \mathrm{a}$ \\
K3 : BP 288 & 22,40 & $62,22 \mathrm{~b}$ & $2,66 \mathrm{~b}$ & $3,76 \mathrm{~b}$ & $2,01 \mathrm{~b}$ \\
K4 : SA 34 & $2,43 \mathrm{tn}$ & $11,35^{\star *}$ & $24,18^{* *}$ & $9,22^{* *}$ & $16,63^{* *}$ \\
\hline F Hitung & 3,05 & 3,05 & 3,05 & 3,05 & 3,05 \\
F Tabel 5\% & 4,63 & 4,63 & 4,63 & 4,63 & 4,63 \\
\hline F Tabel 1\% & 1,84 & 19,03 & 0,92 & 0,74 & 0,57 \\
\hline BNT 5\% & 0,05 & 0,18 & 0,18 & 0,11 & 0,16 \\
\hline KK & & & & &
\end{tabular}

Keterangan:

Angka-angka dalam kolom dan perlakuan yang diikuti dengan huruf yang sama menunjukkan tidak berbeda nyata berdasarkan Uji BNT pada taraf $5 \% .{ }^{* *}=$ Berbeda sangat nyata, ${ }^{*}=$ Berbeda nyata, $\mathrm{tn}=$ Tidak berbeda nyata.

Tabel 3. Angka Rata-rata dan Analisis Statistik Data Komponen Pertumbuhan Setek Klon Kopi Robusta

\begin{tabular}{|c|c|c|c|c|c|}
\hline Perlakuan & $\begin{array}{l}\text { Panjang } \\
\text { akar } \\
(\mathrm{cm})\end{array}$ & $\begin{array}{c}\text { Bobot basah } \\
\text { tanaman } \\
\text { (gram) }\end{array}$ & $\begin{array}{c}\text { Bobot } \\
\text { basah akar } \\
\text { (gram) }\end{array}$ & $\begin{array}{l}\text { Bobot kering } \\
\text { tanaman } \\
\text { (gram) }\end{array}$ & $\begin{array}{l}\text { Bobot } \\
\text { kering akar } \\
\text { (gram) }\end{array}$ \\
\hline \multicolumn{6}{|l|}{ Macam ZPT Alami } \\
\hline M1 : Air Kelapa & $5,85 \mathrm{~b}$ & $5,17 \mathrm{c}$ & $0,78 \mathrm{~b}$ & $0,52 \mathrm{c}$ & $0,08 \mathrm{~b}$ \\
\hline M2 : Ekstrak Kecambah & $5,04 \mathrm{a}$ & $3,66 \mathrm{a}$ & $0,70 \mathrm{a}$ & $0,40 \mathrm{a}$ & $0,07 \mathrm{a}$ \\
\hline M3 : Urin Sapi & $4,87 \mathrm{a}$ & $4,23 \mathrm{~b}$ & $0,69 \mathrm{a}$ & $0,44 \mathrm{~b}$ & $0,06 \mathrm{a}$ \\
\hline F Hitung & $5,87^{\star \star}$ & $10,53^{* *}$ & $3,83^{\star *}$ & $11,21^{* *}$ & $4,02^{*}$ \\
\hline F Tabel 5\% & 3,44 & 3,44 & 3,44 & 3,44 & 3,44 \\
\hline F Tabel 1\% & 5,72 & 5,72 & 5,72 & 5,72 & 5,72 \\
\hline BNT 5\% & 1,27 & 1,38 & 0,14 & 0,11 & 0,02 \\
\hline$\overline{\mathrm{KK}}$ & 0,14 & 0,19 & 0,11 & 0,14 & 0,17 \\
\hline \multicolumn{6}{|l|}{ Macam Klon Kopi Robusta } \\
\hline K1:BP 409 & $5,91 \mathrm{c}$ & $5,03 \mathrm{c}$ & $0,80 \mathrm{~b}$ & $0,53 \mathrm{c}$ & $0,08 \mathrm{~b}$ \\
\hline K2 : BP 42 & $4,98 \mathrm{ab}$ & $4,50 \mathrm{~b}$ & $0,72 \mathrm{a}$ & $0,47 \mathrm{~b}$ & $0,07 \mathrm{a}$ \\
\hline K3 : BP 288 & $4,82 \mathrm{a}$ & $3,49 a$ & $0,67 \mathrm{a}$ & $0,37 \mathrm{a}$ & $0,06 \mathrm{a}$ \\
\hline K4 : SA 34 & $5,32 \mathrm{~b}$ & $4,38 \mathrm{~b}$ & $0,70 \mathrm{a}$ & $0,44 \mathrm{~b}$ & $0,07 \mathrm{a}$ \\
\hline F Hitung & $3,74^{\star}$ & $5,49^{\star \star}$ & $4,39^{*}$ & $10,02^{\star \star}$ & $3,14^{\star}$ \\
\hline F Tabel 5\% & 3,05 & 3,05 & 3,05 & 3,05 & 3,05 \\
\hline F Tabel 1\% & 4,63 & 4,63 & 4,63 & 4,63 & 4,63 \\
\hline BNT 5\% & 1,27 & 1,38 & 0,14 & 0,11 & 0,02 \\
\hline KK & 0,14 & 0,19 & 0,11 & 0,14 & 0,17 \\
\hline
\end{tabular}

Keterangan:

Angka-angka dalam kolom dan perlakuan yang diikuti dengan huruf yang sama menunjukkan tidak berbeda nyata berdasarkan Uji BNT pada taraf $5 \% .{ }^{* *}=$ Berbeda sangat nyata, ${ }^{*}=$ Berbeda nyata, $\mathrm{tn}=$ Tidak berbeda nyata.

Hasil analisis statistik menunjukan bahwa macam zat pengatur tumbuh alami berbeda sangat nyata terhadap persentase setek tumbuh terbesar dicapai pada perlakuan macam zat pengatur tumbuh alami air kelapa muda $\left(\mathrm{M}_{1}\right)$, diikuti ekstrak kecambah 
kacang hijau $\left(\mathrm{M}_{2}\right)$ dan yang terendah adalah urin sapi $\left(\mathrm{M}_{3}\right)$. Pemberian air kelapa pada stek kopi robusta memberikan hasil yang lebih baik dari ekstrak kecambah kacang hijau maupun urin sapi. Kandungan dalam air kelapa yang lebih baik dari kedua ZPT lainnya terutama kandungan auksin yang mampu mencegah terjadinya pengguguran daun setek yang merupakan sumber cadangan makanan utama sebelum tunas muncul. Kandungan auksin tersebut juga mempengaruhi pembelahan sel tanaman sehingga dapat memacu tumbuhnya tunas pada setek lebih cepat. Auksin juga mempunyai kemampuan untuk mengatur pertumbuhan terutama untuk merangsang pembentukan akar. Hal ini sesuai dengan penelitian (Rusmayasari, 2009) di mana pemberian air kelapa muda mampu meningkatkan persentase setek hidup, panjang tunas dan jumlah akar.

Hasil penelitin analisis statistik menunjukan bahwa macam zat pengatur tumbuh alami berpengaruh sangat nyata terhadap variabel panjang tunas dan jumlah daun. Panjang tunas dan jumlah daun tertinggi dicapai pada perlakuan air kelapa muda $\left(\mathrm{M}_{1}\right)$, diikuti ekstrak kecambah kacang hijau $\left(\mathrm{M}_{2}\right)$, dan terakhir urin sapi $\left(\mathrm{M}_{3}\right)$. Pertumbuhan tunas pada stek yang diberi air kelapa lebih cepat dan serempak, hal ini karena adanya kandungan sitokinin yang terdiri atas kinetin dan zeatin pada air kelapa. Menurut Djamhuri (2011) adanya sitokinin memungkinkan terjadinya pembentukan tunas dengan segera dan serempak, mencegah terjadinya pengguguran daun yang lebih dini, terjadinya pembelahan dan pembesaran sel yang lebih aktif. Hal yang sama juga dinyatakan oleh Karimah (2013) yang menyatakan Pada air kelapa 50\% terkandung sitokinin yang berperan sebagai regulator. Sitokinin bekerja sama dengan auksin dapat berperan aktif dalam pembentukan tunas. Jumlah daun erat kaitannya dengan panjang tunas, semakin panjang tunas tanaman maka semakin banyak pula daun yang dihasilkan tanaman.

Hasil penelitian analisis statistik menunjukan bahwa macam zat pengatur tum- buh alami berpengaruh sangat nyata terhadap variabel jumlah akar dan panjang akar. Jumlah akar dan panjang akar tertinggi dicapai pada perlakuan air kelapa muda $\left(\mathrm{M}_{1}\right)$, diikuti ekstrak kecambah kacang hijau $\left(\mathrm{M}_{2}\right)$, dan terakhir urin sapi $\left(\mathrm{M}_{3}\right)$. Hasil percobaan Aguzaen (2009), terlihat bahwa perendaman stek dalam $25 \%$ dan $50 \%$ air kelapa nyata meningkatkan jumlah akar dan panjang akar terpanjang bibit stek dibandingkan dengan control. Sebelumnya Krishnamoorty (1988) melaporkan bahwa untuk mempercepat inisiasi akar stek, memperbanyak jumlah akar per stek, dan meningkatkan persentase stek berakar dapat dilakukan dengan pemberian air kelapa.

Berdasarkan hasil analisis statistik macam zat pengatur tumbuh alami berbeda sangat nyata terhadapat bobot basah tanaman dan bobot kering tanaman. Bobot basah tanaman tertinggi dicapai pada pemberian air kelapa muda $\left(\mathrm{M}_{1}\right)$, diikuti urin sapi $\left(\mathrm{M}_{3}\right)$, sedangakan bobot basah tanaman terendah pada pemberian ekstrak kecambah kacang hijau $\left(\mathrm{M}_{2}\right)$. pemberian air kelapa muda pada stek kopi mampu memberikan hasil yang lebih baik dari ektrak kecambah kacang hijau maupun urine sapi. Gardner dkk. (1991) menyatakan bahwa pertumbuhan adalah pembelahan sel (peningkatan jumlah) dan pembesaran sel (peningkatan ukuran) yang terakumulasi pada berat basah dan berat kering tanaman.

Berat kering tanaman mencerminkan akumulasi senyawa organik yang berhasil disintesis tanaman dari senyawa organik terutama air dan karbohidrat. Menurut Gardner dkk (1991), berat kering tanaman bergantung dari laju fotosintesis dan respirasi. Respirasi menggunakan energi yang berasal dari fotosintesis. Fotosintesis mengakibatkan peningkatkan berat kering karena pengambilan karbondioksida dan respirasi menyebabkan pengeluaran karbondioksida dan mengurangi berat kering.

Berdasarkan hasil analisi statistik macam zat pengatur tumbuh alami berbeda nyata terhadap bobot basah akar dan bobot kering akar. Bobot basah akar tetinggi dica- 
pai pada pemberian air kelapa muda $\left(\mathrm{M}_{1}\right)$ diikuti ekstrak kecambah kacang hijau $\left(\mathrm{M}_{2}\right)$ dan bobot basah terendah pada pemberian urin sapi $\left(\mathrm{M}_{3}\right)$. Air kelapa muda mampu meningkatkan bobot basah/kering akar karena dalam air kelapa muda tidak hanya mengandung auksin saja tetapi juga mineral lainnya. Krishnamoorty (1988) melaporkan bahwa untuk mempercepat inisiasi akar stek, memperbanyak jumlah akar per stek, dan meningkatkan persentase stek berakar dapat dilakukan dengan pemberian air kelapa. Hal ini berhubungan dengan keberadaan zat-zat aktif, terutama auksin dan sitokinin yang berperan dalam merangsang dan memacu inisiasi akar stek.

\section{Pengaruh macam klon kopi robusta}

Hasil analisis statistik macam klon kopi Robusta berbeda sangat nyata terhadap persentase setek tumbuh. Persentase setek tumbuh tertinggi dicapai pada klon kopi Robusta BP $409\left(\mathrm{~K}_{1}\right)$, diikuti oleh klon BP 42 $\left(\mathrm{K}_{2}\right)$, SA $34\left(\mathrm{~K}_{4}\right)$, dan yang terendah dicapai oleh klon BP $288\left(\mathrm{~K}_{3}\right)$. Hal ini karena klon BP 409 memiliki laju fotosintesis yang lebih tinggi sehinggga mengasilkan asimilat yang tinggi pada tanaman, asimilat tersebut menjadi candangan makanan yang disimpan pada daun sebagai sumber makanan utama pada bahan setek. Cadangan makanan yang tinggi ini membuat klon kopi BP 409 lebih mampu bertahan hidup sampai setek benar-benar bertunas dan berakar.

Hasil analisis statistik macam klon kopi Robusta berbeda sangat nyata terhadap variabel panjang tunas dan jumlah daun. Panjang tunas dan jumlah daun tertinggi dicapai oleh klon BP $409\left(\mathrm{~K}_{1}\right)$ kemudian BP $42\left(\mathrm{~K}_{2}\right)$ dan SA $34\left(\mathrm{~K}_{4}\right)$ dan terendah BP $288\left(\mathrm{~K}_{3}\right)$. Klon BP 409 memiliki hasil yang lebih baik dibanding klon lainya karena mempunyai respon yang lebih baik terhadap pemberian zat pengatur tumbuh dari luar sehingga dapat memacu hormon auksin yang sudah ada pada tanaman yang membuat tanaman mengalami pemanjang sel yang lebih baik.

Berdasarkan hasil percobaan (Sumirat. dkk, 2013) analisis sifat-sifat pertumbuhan stek kopi robusta, menyatakan bahwa secara keseluruhan pertumbuhan pertunasan pada hampir semua genotipe yang diujikan menunjukkan pertumbuhan yang baik. Hasil penelitian Purwadi \& Taqwim (1995) menunjukkan bahwa pertumbuhan setek untuk karakter jumlah tunas pada beberapa genotipe kopi Robusta tidak berbeda, namun sebaliknya berbeda nyata pada karakter panjang tunas dan berat kering tunas. Hasil ini juga diperkuat oleh Budijanto (2004) dan Madjid (2007) yang memperlihatkan hasil yang tidak berbeda pada karakter jumlah tunas, dan sebaliknya menunjukkan berbeda pada karakter panjang tunas. Selanjutnya, dinyatakan bahwa karakter pertumbuhan jumlah tunas setek tampaknya tidak banyak dipengaruhi oleh faktor genetik.

Jumlah daun sangat dipengaruhi oleh panjang tunas tanaman, semakin panjang tunas maka daun yang dihasilkan juga akan semakin banyak. Hormon auksin yang ada didalam tanaman serta penambahan dari luar mampu memacu pertumbuhan tunas pada setek sehingga panjang tunas dan jumlah daun akan meningkat (Darlina dkk, 2016).

Hasil analisis statistik menunjukan macam klon kopi Robusta berbeda sangat nyata terhadap variabel jumlah akar dan berbeda nyata pada panjang akar trepanjang. Jumlah akar dan panjang akar trepanjang dicapai oleh klon BP $409\left(\mathrm{~K}_{1}\right)$, diikuti BP $42\left(\mathrm{~K}_{2}\right)$ dan SA $34\left(\mathrm{~K}_{4}\right)$ dan terakhir BP 288 $\left(\mathrm{K}_{3}\right)$. Klon BP 409 mampu memberikan hasil yang lebih baik karena memiliki sifat genetik yang terbilang cukup mudah berakar. Hal ini sesuai dengan hasil pada percobaan yang dilakuakan (Sumirat dkk. 2013), klon BP 409 masuk pada gerombol pecahan Kedua, kedua gerombol tampak lebih dominan dalam pembentukan tunas dari pada pembentukan akar, namun gerombol pecahan kedua memiliki keseimbangan pertumbuhan yang jauh lebih baik dari pada gerombol pecahan pertama.

Hasil analisis statistik macam klon kopi Robusta berbeda sangat nyata terhadap variabel bobot basah tanaman dan bobot kering tanaman. Bobot basah dan bobot kering tanaman terbesar dicapai oleh klon BP 
$409\left(\mathrm{~K}_{1}\right)$ diikuti BP $42\left(\mathrm{~K}_{2}\right)$ dan SA $34\left(\mathrm{~K}_{4}\right)$ dan terendah BP $288\left(K_{3}\right)$. Hal ini karena klon BP 409 memiliki morfologi tanaman yang besar serta daun yang lebih besar yang membuat laju fotosintesisnya lebih tinggi.

Berat basah merupakan indikator pertumbuhan yang berkaitan dengan air dan karbohidrat. Menurut Fitter dan Hay (1998), secara fisiologis berat basah biasanya terdiri dari dua kandungan yaitu air dan karbohidrat. Air merupakan komponen utama tanaman hijau yang merupakan $70-90 \%$ dari berat segar tanaman tersebut. Pembentukan jaringan dan organ tanaman ditentukan oleh proses fotosintesa karena energi yang dihasilkan dari proses fotosintesa digunakan untuk pembelahan, perpanjangan dan diferensiasi sel. Dalam hal ini jumlah dan luas daun menentukan banyaknya fotosintat yang dihasilkan, semakin banyak sel dalam jaringan tanaman semakin banyak air yang terkandung sehingga menentukan berat segar suatu tanaman. Hal ini sesuai dengan pernyataan Arjenaki dkk, (2012) bahwa kandungan klorofil merupakan salah satu factor utama yang mempengaruhi kapasitas fotosintesis. Kandungan klorofil daun dapat dijadikan indikator kemampuan fotosintesi jaringan tanaman.

Luas daun juga sangat berpengaruh terhadap produksi karena daun adalah organ utama berlangsungnya fotosintesis. Dengan jumlah daun, luas daun, dan jumlah cabang yang lebih banyak memungkinkan semakin besarnya tajuk tanaman dan berpengaruh terhadap hasil fotosintesis tanaman. Ukuran luas daun memiliki peran dalam fotosintesis yang terjadi pada daun. Hasil fotosintesis per satuan tanaman ditentukan oleh luas daun. Dengan luas permukaan daun yang lebih besar maka memungkinkan menangkap cahaya yang lebih baik pula sehingga memiliki nilai hasil fotosintesis yang lebih tinggi. Kopi robusta klon BP 409 memiliki luas daun yang lebar (Ristiawan, 2011).

Bobot kering tanaman mencerminkan akumulasi senyawa organik yang berhasil disintesis tanaman dari senyawa organik terutama air dan karbohidrat. Menurut Gardner dkk., (1991), berat kering tanaman bergantung dari laju fotosintesis dan respirasi. Respirasi menggunakan energi yang berasal dari fotosintesis. Fotosintesis mengakibatkan peningkatkan berat kering karena pengambilan karbondioksida dan respirasi menyebabkan pengeluaran karbondioksida dan mengurangi berat kering. Pertumbuhan tanaman ditunjukkan oleh pertambahan ukuran dan berat kering tanaman. Untuk mengukur produktivitas tanaman akan lebih relevan menggunakan berat kering brangkasan atau bagian tanaman sebagai ukuran pertumbuhan (Salisbury dan Ros, 1995).

Hasil analisis statistik macam klon kopi Robusta berbeda nyata terhadap variabel bobot basah akar dan bobot kering akar. Bobot basah akar dan bobot kering akar tertinggi dicapai oleh klon BP $409\left(K_{1}\right)$, diikuti BP $42\left(\mathrm{~K}_{2}\right)$ dan SA $34\left(\mathrm{~K}_{4}\right)$, kemudian yang terendah adalah klon BP $288\left(\mathrm{~K}_{3}\right)$. Peranan akar dalam pertumbuhan tanaman sama pentingnya dengan tajuk. Kalau tajuk berfungsi untuk menyediakan karbohidrat melalui proses fotosintesis, maka fungsi akar adalah menyediakan unsur hara dan air yang diperlukan dalam metabolisme tanaman. Menurut Harjadi (1996) karbohidrat yang dihasilkan oleh daun sebagai hasil proses fotosintesis yang berhubungan juga dengan proses transpirasi, dapat menstimulir pembentukan akar. Panjang akar yang dihasilkan secara tidak langsung juga dapat mempengaruhi berat akar yang dihasilkan. Semakin panjang akar yang dihasilkan, maka semakin berat pula akar yang dihasilkan.

Menurut Gardner dkk, (1991) berat kering merupakan parameter pengukuran yang mencerminkan banyaknya asimilat yang dihasilkan tanaman, sedangkan menurut Harjadi (1996) bahwa berat kering tanaman pada prinsipnya merupakan hasil berat segar tanaman yang dihilangkan kandungan airnya dan pada akhirnya yang tersisa adalah bahan organik yang hidup dalam bentuk biomassa. Peningkatan berat kering melalui peningkatan hasil fotosintesa disebabkan oleh terpenuhinya kebutuhan air dan unsur hara. Selain pemberian zat pe- 
ngatur tumbuh alami, penggunaan media tanam yang baik juga dapat mempengaruhi pertumbuhan akar, penambahan pupuk kandang dalam media tanam dapt memenuhi kebutuhan hara untuk akar sehingga dapat meningkatkan bobot basah maupun bobot kering akar.

Tabel 4. Angka Rata-rata Interaksi Antara Macam ZPT Alami dan Macam Klon Kopi Robusta Terhadap Panjang Tunas, Jumlah Akar, Bobot Basah Tanaman, dan Bobot Kering Tanaman.

\begin{tabular}{lllll}
\hline Perlakuan & $\begin{array}{l}\text { Panjang tunas } \\
\text { (cm) }\end{array}$ & $\begin{array}{l}\text { Jumlah akar } \\
\text { (buah) }\end{array}$ & $\begin{array}{l}\text { Bobot basah tanaman } \\
\text { (gram) }\end{array}$ & $\begin{array}{l}\text { Bobot kering tanaman } \\
\text { (gram) }\end{array}$ \\
\hline M1K1 & $5,88 \mathrm{f}$ & $3,40 \mathrm{e}$ & $6,77 \mathrm{~d}$ & $0,68 \mathrm{f}$ \\
M1K2 & $4,08 \mathrm{de}$ & $2,67 \mathrm{~d}$ & $5,36 \mathrm{c}$ & $0,55 \mathrm{e}$ \\
M1K3 & $2,47 \mathrm{abc}$ & $1,47 \mathrm{a}$ & $3,06 \mathrm{a}$ & $0,32 \mathrm{a}$ \\
M1K4 & $3,19 \mathrm{cde}$ & $2,20 \mathrm{bcd}$ & $5,49 \mathrm{c}$ & $0,52 \mathrm{de}$ \\
M2K1 & $3,24 \mathrm{cde}$ & $2,40 \mathrm{~cd}$ & $3,67 \mathrm{ab}$ & $0,46 \mathrm{cde}$ \\
M2K2 & $2,81 \mathrm{bcd}$ & $2,33 \mathrm{bcd}$ & $3,51 \mathrm{ab}$ & $0,39 \mathrm{abc}$ \\
M2K3 & $2,19 \mathrm{ab}$ & $1,80 \mathrm{ab}$ & $3,55 \mathrm{ab}$ & $0,34 \mathrm{ab}$ \\
M2K4 & $2,64 \mathrm{abc}$ & $1,83 \mathrm{ab}$ & $3,89 \mathrm{ab}$ & $0,40 \mathrm{abc}$ \\
M3K1 & $3,61 \mathrm{cde}$ & $2,27 \mathrm{bcd}$ & $4,64 \mathrm{bc}$ & $0,45 \mathrm{bcd}$ \\
M3K2 & $2,96 \mathrm{bcd}$ & $1,87 \mathrm{abc}$ & $4,63 \mathrm{bc}$ & $0,47 \mathrm{cde}$ \\
M3K3 & $1,86 \mathrm{a}$ & $1,53 \mathrm{a}$ & $3,87 \mathrm{ab}$ & $0,44 \mathrm{bcd}$ \\
M3K4 & $2,15 \mathrm{ab}$ & $2,00 \mathrm{abc}$ & $3,77 \mathrm{ab}$ & $0,41 \mathrm{abc}$ \\
\hline F Hitung & $3,02^{\star}$ & $2,97^{*}$ & $3,20^{*}$ & $4,44^{* *}$ \\
F Tabel 5\% & 2,55 & 2,55 & 2,55 & 2,55 \\
F Tabel 1\% & 3,76 & 3,76 & 3,76 & 3,76 \\
\hline BNT 5\% & 0,92 & 0,57 & 1,38 & 0,11 \\
\hline KK & 0,18 & 0,16 & 0,19 & 0,14 \\
\hline
\end{tabular}

Keterangan:

Angka-angka dalam kolom dan perlakuan yang diikuti dengan huruf yang sama menunjukkan tidak berbeda nyata berdasarkan Uji BNT pada taraf $5 \% .{ }^{* *}=$ Berbeda sangat nyata, ${ }^{*}=$ Berbeda nyata, $\mathrm{tn}=$ Tidak berbeda nyata.

Pengaruh interaksi antara macam Zat Pengatur Tumbuh alami dan macam klon kopi robusta

Hasil analisis statistik menunjukan bahwa terdapat interaksi antara macam zat pengatur tumbuh alami dengan macam klon kopi Robusta terhadap panjang tunas tanaman. Kombinasi terbaik dicapai pada macam zat pengatur tumbuh alami air kelapa muda dan macam klon kopi Robusta BP 409 $\left(\mathrm{M}_{1} \mathrm{~K}_{1}\right)$.

Kombinasi macam zat pengatur tumbuh alami dan macam klon kopi Robusta akan membantu meningkatkan panjang tunas. Menurut Rusmin (2011) kandungan auksin yang terdapat dalam air kelapa muda mempengaruhi pemanjangan sel pada tanaman, Pemanjangan sel yang yang terjadi pada tunas. Selain auksin hormon yang juga memacu pertumbuhan tunas adalah sitokinin. Menurut Djamhuri (2011) adanya sitokinin memungkinkan terjadinya pembentukan tunas dengan segera dan serempak, mencegah terjadinya pengguguran daun yang lebih dini, terjadinya pembelahan dan pembesaran sel yang lebih aktif. Adanya zat tumbuh yang ada dalam tubuh tanaman maupun hormon yang diberikan mampu memacu proses pertumbuhan tunas. Tidak ada perbedaan jumlah tunas antar klon kopi Robusta tetapi terdapat perbedaan panjang tunas antar klon.

Hasil analisis statistik menunjukan bahwa terdapat interaksi antara macam ZPT alami dan macam klon kopi Robusta terha- 
dap variabel jumlah akar. Kombinasi perlakuan terbaik adalah macam zat pengatur tumbuh air kelapa muda dan macam klon kopi Robusta BP $409\left(\mathrm{M}_{1} \mathrm{~K}_{1}\right)$. Kombinasi perlakuan ini memberikan hasil yang lebih baik terhadap variabel jumlah akar. Hal ini karena kandungan auksin yang terdapat pada air kelapa mampu untuk memacu tumbuhnya akar serta sifat genetik klon BP 409 yang mampu menghasilkan banyak akar. Trisna (2013) mengemukakan bahwa pemberian zat pengatur tumbuh bertujuan untuk mempercepat proses fisiologi pada tanaman yang memungkinkan tersedianya bahan pembentuk organ vegetatif. Pemberian ZPT dengan konsentrasi yang tepat akan memacu pertumbuhan akar, seperti hasil penelitian Rusmayasari (2006) yang menunjukkan bahwa pemberian air kelapa $100 \%$ dapat meningkatkan jumlah akar dan panjang akar stek pucuk Shorea selanica. Auksin dalam air kelapa juga dapat merangsang dan membantu sel kalus (yang dihasilkan dari bagian batang yang terpotong) untuk berdiferensiasi membentuk akar.

Kombinasi macam zat pengatur tumbuh alami dan macam klon kopi Robusta membantu meningkatkan bobot basah dan bobot kering tanaman. Menurut (Ristiawan, 2011) menyataan klon kopi robusta BP 409 memiliki perawakan besar kokoh, percabangan kokoh dan kuat dengan ruas agak panjang ditambah zat pengatur tumbuh yang berfungsi sebagai pengatur yang dapat mempengaruhi jaringan-jaringan berbagai organ maupun sistem organ sehingga dapat menambah bobot basah tanaman (Lingga, 1986). Bobot basah merupakan bobot yang diperoleh dari keseluruhan bagian tanaman meliputi akar, batang dan daun. Bobot basah sejalan dengan pertumbuhan vegetatif, di mana semakin baik pertumbuhannya maka bobot basah semakn tinggi.

Bobot kering berhubungan erat dengan bobot basah suatu tanaman, apabila bobot basahnya tinggi maka bobot keringnya juga tinggi. Menurut (Widodo, 2015) dalam penelitiannya menyatakan bahwa Bp 409 mempunyai sifat genetik dimana mempunyai metabolisme yang tingi, terutama fotosintesis. Tanaman yang memiliki laju fotosintesis tinggi mampu menghasilkan fotosintat dalam jumlah besar berupa karbohidrat, lemak dan protein, kemudian protein akan menghasilkan pertambahan dari ukuran sel tanaman serta penimbunan karbohidrat dalam bobot kering tanaman, bobot kering tanaman merupakan hasil penimbunan bersih asimilat sepanjang pertumbuhan tanaman.

\section{KESIMPULAN}

1. Macam zat pengatur tumbuh alami berbeda sangat nyata terhadap persentase setek tumbuh, panjang tunas, jumlah daun, jumlah akar, panjang akar, bobot basah tanaman, bobot kering tanaman dan berbeda nyata terhadap kecepatan setek tumbuh, bobot basah akar dan bobot kering akar. Macam zat pengatur tumbuh alami terbaik untuk pertumbuhan setek kopi Robusta adalah air kelapa muda.

2. Macam klon kopi Robusta berbeda sangat nyata terhadap variabel persentase setek tumbuh, panjang tunas, jumlah daun, jumlah akar, bobot basah tanaman, bobot kering tanaman dan berbeda nyata terhadap variabel panjang akar, bobot basah akar dan bobot kering akar. Klon kopi Robusta yang pertumbuhan seteknya terbaik adalah klon BP 409.

3. Terdapat interaksi antara macam zat pengatur tumbuh alami dan macam klon kopi Robusta berbeda nyata terhadap variabel panjang tunas, panjang akar, bobot basah tanaman dan berbeda sangat nyata terhadap variabel bobot kering tanaman. Kombinasi terbaik pada pertumbuhan setek beberapa klon kopi Robusta dicapai pada pemberian zat pengatur tumbuh alami air kelapa muda dan klon kopi Robusta BP 409.

\section{DAFTAR PUSTAKA}

Aguzaen, Hendra. 2009. Respon Pertumbuhan Bibit Stek Lada (Piper Nisrum L.) Terhadap Pemberian Air Kelapa dan Berbagai Jenis CMA. Journal Agronobis Vol : 1, No : 1. 
Arjenaki FG, R Jabbari, A Morshedi. 2012. Evaluation of drought stress on relative water content, chlorophyll content and mineral elements of Wheat (Triticum aestivum L.) varieties. International Journal of Agriculture and Crop Sciences. 4:726-729.

Bhimas. 2010. Pengaruh Ekstrak Touge Kacang Hijau Terhadap Perkecambahan Seledri (Apium Graveolens L.). http://bhimashraf. blogspot.com/2010/12/pengaruhekstrak-touge-kacang- hijau.html.

Budijanto. 2004. Analisis Daya Gabung dan Korelasi Genotipik Sifat Perakaran dan Pertunasan Setek dengan Sifat Pertumbuhan Bibit Kopi Robusta. Tesis, Magister Pertanian, Universitas Jember.

Darlina., Hasanudin., H, Rahmatan. 2016. Pengaruh Penyiraman Air Kelapa (Cocos nucifera L.) terhadap Pertumbuhan Vegetatif Lada (Piper nigrum L).

Direktoriat Jendral Perkebunan Kementrian Pertanian. 2013. Kebijakan Pengembangan Kopi Nasional. Jakarta.

Djamhuri, Edje. 2011. Pemanfaatan Air Kelapa untuk Meningkatkan Pertumbuhan Stek Pucuk Meranti Tembaga (Shorea leprosula Miq). Jurnal Silvikultur Tropika Vol: 02 No: 01.

Fitter, A. H dan R. K. M. Hay. 1998. Fisiologi Lingkungan Tanaman. Gajah Mada University Press. Yogyakarta.

Harjadi, S.S. 1996. Pengantar Agronomi. Gramedia. Jakarta.

Kiptiyah, Mariyatul. Upaya Peningkatan Pertumbuhan Stek Kopi Robusta Melalui Pemberian NAA Pada Komposisi Media yang Berbeda. Skripsi. Fakultas Pertanian Universitas Pekalongan. Pekalongan. 2005.

Krishnamoorthy, W., S. Harran dan P. Tjondronegoro. 1988. Dasar-Dasar Fisiologi Tumbuhan. Jilid I. Bogor: Departemen Botani Fakultas Pertanian IPB.
Lingga, P. 1986. Bertanam Umbi-umbian. Penebar Swadaya. Jakarta.

Madjid, A. 2007. Pendugaan Daya Gabung dan Ragam Genetik Sifat-Sifat Agronomi Setek Klon Kopi Robusta (Coffea canephora Pierre var. Robusta Cheval.). Tesis, Magister Pertanian, Universitas Jember.

Purwadi, B. \& M. Taqwim (1995). Kajian keragaman genetik sifat perakaran setek kopi robusta (Coffea canephora Pierre var. Robusta Cheval.). Prosiding Simposium Pemuliaan Tanaman III, Jember, 47-52.

Raharjo, Pudji. 2012. Panduan Budidaya dan Pengolahan Kopi Arabika dan Robusta. Jakarta: Swadaya.

Ristiawan, Andri Pradana. 2011. Karakter Dua Klon Kopi Robusta Pada Jenis Penaung yang Berbeda. Skripsi. Fakultas Pertanian Universitas Jember.

Rusmayasari. 2006. Pengaruh Pemberian IBA, NAA dan Air Kelapa terhadap Pertumbuhan Stek Pucuk Meranti Bapa (Shorea solanica BL.). Skripsi. Institute Pertanian Bogor.

Salisbury, F. dan C.W. Ross. 1995. Fisiologi Tumbuhan Jilid III : Perkembangan Tumbuhan dan Fisiologi Lingkungan. Terj. ITB. Bandung.

Sari, Mei Puspita. 2009. Pengaruh Lama Perendaman Dalam Urine Sapi dan Dosis Pupuk Kandang Sari terhadap Pertumbuhan Setek Nilam. Skripsi. Fakultas Pertanian Universitas Sebelas Maret. Surakarta.

Sari, Y. P., H. Manurung, dan Aspiah. 2011.Sistem Informasi Kesesuaian Lahan Tanaman Kakao (Theobroma cacao L). Mulawarman Scientifie, 10 (2): 219- 231. http://fmipa.unmul.ac.id/pdf/25

Sumirat, Ucu., F, Yuliasmara, Priyono. 2013. Analisis Sifat-Sifat Pertumbuhan Setek Kopi Robusta (Coffea canephora). Jurnal Pelita Perkebunan.

Sutedjo, M. M. 2008. Pupuk dan Cara Pemupukan. Rineka Cipta. Jakarta. 82 hal Widodo, Tirto Wahyu. 2015. 
Karakter Fisiologis Kopi Robusta (Coffea canephora) Klon BP 409 dan BP 936 Pada Persentase Kapasitas Lapang yang Berbeda. Skripsi. Fakultas Pertanian Universitas Jember.
Yunita R. 2011.Pengaruh Pemberian Urine Sapi, Air Kelapa, Dan Rootone $F$ Terhadap Pertumbuhan Setek Tanaman Markisa (Passiflora Edulis Var. Flavicarpa). Universtas Andalas. Sumatera Utara. http://repository. unand.ac.id/16864/1/JURNAL.pdf. 